\title{
Education for Cataloging in Spanish Universities: A Descriptive and Critical Study
}

\author{
Rafael Ruiz-Perez \\ Emilio Delgado López-Cózar
}

\begin{abstract}
SUMMARY. Objective: This is a critical descriptive study of the situation of cataloging as an academic discipline within Library and Information Science studies in Spain. Material and methods: The descriptive analysis of the sectional contents of the general and specific guidelines of the degrees of Diplomado (three-year degree) and Licenciado (fiveyear degree) in LIS and the curricular programs of the Spanish university schools or departments. Variables analyzed: The denomination and content descriptors of the course offerings and credit hours. The test-retest method was used, with a qualitative processing of data. Results: General data is given about the studies in LIS: their introduction, the universities that offer them, and the degrees awarded. Cataloging is considered an obligatory core subject matter, and is represented by several
\end{abstract}

Rafael Ruiz-Perez, PhD, is Professor of Library and Information Science Documentation, Universidad de Granada, Facultad de Biblioteconomía y Documentación, Campus Universitario de Cartuja, 18071 - Granada, Spain (E-mail: rruiz@ugr.es). Emilio Delgado López-Cózar, PhD, is Professor of Library and Information Science Documentation, Universidad de Granada, Facultad de Biblioteconomía y Documentación, Campus Universitario de Cartuja, 18071 - Granada, Spain.

[Haworth co-indexing entry note]: "Education for Cataloging in Spanish Universities: A Descriptive and Critical Study.” Ruiz-Perez, Rafael, and Emilio Delgado López-Cózar. Co-published simultaneously in Cataloging \& Classification Quarterly (The Haworth Information Press, an imprint of The Haworth Press, Inc.) Vol. 41, No. 3/4, 2006, pp. 291-307; and: Education for Library Cataloging: International Perspectives (ed: Dajin D. Sun, and Ruth C. Carter) The Haworth Information Press, an imprint of The Haworth Press, Inc., 2006, pp. 291-307. Single or multiple copies of this article are available for a fee from The Haworth Document Delivery Service [1-800-HAWORTH, 9:00 a.m. - 5:00 p.m. (EST). E-mail address: docdelivery@haworthpress.com].

Available online at http://www.haworthpress.com/web/CCQ

(C) 2006 by The Haworth Press, Inc. All rights reserved. doi:10.1300/J104v41n03_06 
courses that present important differences insofar as their denominations, their credits, and their character from one curricular program to the next. The average credit requisite for obligatory courses in cataloging in Spain is 14 ( 1 credit $=10$ class hours), and 19.7 if electives are also considered. At present, this discipline is undergoing a reform that will produce important changes as a result of the adaptation of university studies to the common framework of the European Union. [Article copies available for a fee from The Haworth Document Delivery Service: 1-800-HAWORTH. E-mail address: <docdelivery@haworthpress.com> Website: <http://www.HaworthPress.com> () 2006 by The Haworth Press, Inc. All rights reserved.]

KEYWORDS. Library and Information Science (LIS), Spain, cataloging, cataloging education, teaching, curricula, professional instruction

\section{INTRODUCTION}

The importance that cataloging has historically had in the context of the universal bibliographic control of publications cannot be underestimated. This was made quite clear by Michael Gorman in his paper presented at the 67th IFLA General Conference and Council, Boston, USA, August 16-25, 2001, ${ }^{1}$ when he underlined the significance of the initiatives carried out over the last 30 years insofar as the international standardization of cataloging rules and formats (ISBD, AACR2, and MARC). It is only fair to acknowledge the meritorious role that cataloging continues to play in the preparation of professionals for library and documentary services.

During the first half of the 20th century, in the U.S., widespread consensus already existed that cataloging should be core material in the educational programs for Library and Information Science (LIS) professionals. More recently, a study by G. A. Marco in 1994 showed that only two subjects, one of them cataloging, are required as a core course in over $50 \%$ of the U.S. schools of LIS accredited by the ALA. ${ }^{2}$ At present, most of the ALA-accredited programs ${ }^{3}$ impart, to different degrees, contents related to cataloging and to the study of standards used in bibliographic control.

At the international level, organizations tied to the field of Libraries, Documentation and Information, such as IFLA, UNESCO, or FID, have worked intensely to elaborate standards, guidelines, and directives re- 
garding instruction in LIS, with cataloging always occupying a basic modular position as an academic discipline. $4,5,6,7$

At this point in time, we would like to describe and assess the way that current curricula reflect this international recognition of cataloging officially, in the different studies that have formalized programs for Library and Information Science. We gladly contribute to this volume to offer an overview of cataloging in Spanish academic institutions.

As has occurred in other countries, a number of publications and studies here have tried to analyze the historic development of LIS academics on an international level, ${ }^{8}$ as well as the evolution of the training of professional librarians. ${ }^{9}$ There are also a number of studies on the gestation of LIS in Spain, ${ }^{10,11}$ looking at the overall organization of its contents and its thematic characterization. ${ }^{12}$ Finally, there are studies about the teaching of specific subjects such as Information Sources, ${ }^{13}$ Information Technology, ${ }^{14}$ Research Methods and Techniques ${ }^{15}$ or Information Retrieval. ${ }^{16}$ Yet, until now, no study has focused precisely on the in-depth analysis of cataloging as an academic discipline.

Therefore, the purpose of this study will be to bridge this gap with a critical and comparative analysis of how the subject matter "Descriptive Cataloging" is represented in the different curricular plans of the LIS degrees from Spanish institutions.

\section{MATERIAL AND METHODS}

First, we present a descriptive analysis of the sectional contents of Cataloging, as expressed in the general and specific guidelines for the degrees of Diplomado and Licenciado in Library and Information Science, and for the Licenciatura in Information Science alone. Secondly, we apply this analysis to the representation of cataloging in the different curricula of the schools and departments that offer LIS degrees. The data sources used include the aformentioned directives, which are published in the Official Bulletin of the Spanish Government (BOE), as well as the curricular plans consulted on the web pages of the Schools of Spanish Universities.

The general guidelines for the degrees and the curricular programs give information about the following variables: denomination and descriptors of the contents of subjects and the respective courses, the course credit load, and the area of knowledge where it is imparted. To control the reliability of the observations made, we used the test-retest method, and the data were processed qualitatively. It should be men- 
tioned that one of the data sources used (the University School web sites) may introduce bias in the results obtained, given that this information is conditioned by the policy of each particular center. In other words, the programs on web pages, even when available, may not have been complete, or may not correspond exactly with what is actually imparted. In Spain it is obligatory to provide such programs in the departments, but it is not obligatory to put them on the Web. On the other hand, the age of the web information could also be variable. It is known that one indicator of the quality of a web page is its degree of currency. An unwritten law recommends that the latest date of revision of the contents be indicated at the foot of the page (screen).

\section{RESULTS}

General Data About the Studies of Library and Information Science in Spain

The official incorporation of studies in LIS into the Spanish University is fairly recent. The three-year degree known as Diplomatura was established by Royal Decree in 1978, and the first university initiative was set in motion in 1981. This first cycle consisted of basic instruction and formation in general, to prepare the student for professional activity. At present these studies are offered in 12 universities: Barcelona, Carlos III de Madrid, Complutense de Madrid, La Coruña, Extremadura, Granada, León, Murcia, Salamanca, Valencia, Vic, and Zaragoza. There were 4,734 students enrolled in these programs during the academic year 2002-2003. ${ }^{17}$

The Licenciatura in Information Science, which completes or complements university undergraduate education, was established in 1992 (Real Decreto 912/1992). This second cycle, with a duration of two years, is dedicated to specialization in the field and prepares students for exercising the profession in the direction of centers of documentation and the management of information. At present this degree is offered in 11 university schools: Alcalá de Henares, Autónoma de Barcelona, Barcelona, Carlos III de Madrid, Complutense de Madrid, Extremadura, Granada, Murcia, Oberta de Catalunya, Salamanca, and Valencia, with a total enrollment of 2,279 students for 2002-2003. ${ }^{18}$

The third cycle or Doctorate program is designed for preparing professors and researchers. There are now LIS Doctorate Programs in Spain at the universities of Alcalá de Henares, Carlos III de Madrid, 
Complutense de Madrid, Granada, Murcia, Salamanca, Valencia, and Zaragoza, with some 100 graduates enrolled.

In all of these cycles, courses are counted by credits, with a credit the equivalent of ten hours of practical or theoretical instruction. As for contents, we will focus on the presence of core courses of obligatory inclusion all over Spain. The rest of the subjects taught are either obligatory courses that are specified by each university, or optional material specific to each university as well, but of free choice for the student.

\section{Cataloging in the Specific Guidelines for the LIS Diplomatura: A Critical Analysis}

In Spain the educational system, including higher education, is a public service and, therefore, the government is in charge of establishing its ground rules. University studies are subject to general directives and specific guidelines; these rules expound and regulate the basic curricular characteristics that each academic degree is to have in the entire national territory. In the specific guidelines for the elaboration of the plans of study of the Diplomaturas in LIS, whose latest reform was passed in 1991 (Real Decreto 1422/1991, August 30), there is a listing of the core courses that are obligatory for all centers that offer such a degree. The consideration of cataloging as core course content (Table 1) has led, as we shall see later, to its automatic inclusion in all of the curricula of the University LIS Schools and Departments.

A first look at Table 1 shows the area which includes Cataloging-Documentary Analysis and Languages-to be the most important in terms of material and credits. Moreover, among the descriptors of the material, most correspond to cataloging.

On the other hand, we concede that the very denomination of the subject matter is unfortunate. As J. A. Frias ${ }^{19}$ points out, the clearest incoherence is seen in that one of the descriptors, "Information Management and Retrieval," is even more generic than the subject matter it is included in (and would, in fact, be a more appropriate name for the course). Indeed, the material it attempts to describe is that embracing all of the disciplines related to the techniques of information retrieval and processing, such as: Access to Description (Access Points), Elaboration of Catalogs, Theory and Structure of the Classification and Indexing Systems, and Analysis of Contents. In a future revision of the guidelines, therefore, it could be recommended that we change the denomination "Documentary Analysis and Languages" to "Information Processing and Retrieval." 
TABLE 1. Specific Guidelines for the Curricula for the Diplomatura Degree in LIS in Spain: Core (Compulsory) Subjects

\begin{tabular}{|l|c|l|}
\hline \multicolumn{1}{|c|}{ Core Course Title } & Credits & \multicolumn{1}{c|}{ Description of Contents } \\
\hline Análisis y Lenguajes Documentales & 20 & $\begin{array}{l}\text { Introduction to cataloging and classification. } \\
\text { Information management and retrieval. } \\
\text { Bibliographic description of documents in } \\
\text { different formats: access to the description and } \\
\text { elaboration of catalogs. Theory and structure of } \\
\text { classifications and indexing systems. Content } \\
\text { analysis. }\end{array}$ \\
\hline Archivística & 10 & $\begin{array}{l}\text { Introduction to the study and organization of } \\
\text { archives. }\end{array}$ \\
\hline Bibliografía y Fuentes de Información & 10 & $\begin{array}{l}\text { Nature, function, and typology of general and } \\
\text { specific documentary sources. }\end{array}$ \\
\hline Biblioteconomía & 10 & $\begin{array}{l}\text { Organization and administration of libraries and in- } \\
\text { formation centers. }\end{array}$ \\
\hline Documentación General & 10 & Study of the concept of documentary information. \\
\hline $\begin{array}{l}\text { Técnicas Historiográficas de la } \\
\text { Investigación Documental }\end{array}$ & 6 & $\begin{array}{l}\text { Applied paleography, diplomatics, and } \\
\text { numismatics. }\end{array}$ \\
\hline Tecnología de la Información & 15 & $\begin{array}{l}\text { Technologies of conservation and retrieval of } \\
\text { information. }\end{array}$ \\
\hline Practicum & 10 & $\begin{array}{l}\text { Professional practice in libraries and information } \\
\text { centers or systems. }\end{array}$ \\
\hline
\end{tabular}

The descriptors that specify the contents of the subject must be qualified as scanty and indiscriminately formulated, but above all there is an obviously poor correspondence between the descriptors and the contents they attempt to describe. In following the Anglo-Saxon terminology and the logical order of the techniques for processing bibliographic information, in our opinion, the most correct denominations to designate all of the operations involved in cataloging and elaborating catalogs are: "Descriptive Cataloging" to refer to the bibliographic description of the documents, to the choice of access points and to their standardization as entries to the information in the catalog (Heading); and on the other hand, "Cataloging by Subject Matter" to refer to the formulation of the Subject Heading. The term "Classification or Classification Systems" would have been adequate as well for referring to systematic indexing or classificatory notations (Classification). Finally, the descriptor "Analysis of Contents" is possibly the best, though we might also directly use "Documentary Summary" (Abstract or Summary) to refer to the operation which consists of creating an abbreviated representation of the contents.

The credit load (20 credits $=200$ hours $)$ assigned to this subject calls for some clarification. Bearing in mind that each university can freely 
organize the core material into specific disciplines or subjects, we believe that the material within Documentary Analysis and Languages should be divided into at least four areas. But this would mean each subject ending up with five credits, a totally insufficient load in any case. For instance, for a course in "Descriptive Cataloging," it would be practically impossible to teach, in a total of 50 hours, the theoretical and practical contents of the International Standard Bibliographic Description (ISBD), the assignment and form of access points or "Headings" (Reglas de Catalogación Españolas or RCE and AACR2), the presentation of data in a computerized format (MARC and IBERMARC), and the formation of authority records (GARE, GSARE, and MARC Authorities). In our view, the student should acquire a critical scientific attitude about the need to change the standards used to create bibliographic records, ${ }^{20}$ well aware of their importance for the development of future work in the field, and for the advancement of the methodologies and tools of bibliographic control in the context of new technologies.

Therefore, to properly develop the contents we have described, at least two courses in cataloging would be necessary, with the following characteristics: that they be part of the core curriculum, compulsory, and annual, with 10 credits corresponding to each.

Because time is also a factor, and this point admits no debate, we the professors must strive to reconcile two contrasting needs: on the one hand, to adapt contents of subjects to the time available, and on the other hand, to try not to sacrifice any fundamental aspects in our exposition of the material. Actually, these two interests cannot be made entirely compatible, and as the first is more impending than the second, we are left omitting contents as a partial solution. Or, perhaps, as the only possible solution.

\section{Descriptive Cataloging in the LIS Curricula in Spain}

Given that the directives regulating the awarding of degrees in Spain establish subject matter and not subjects per se, and that the principle of university autonomy is a cornerstone of the Spanish educational system, the different universities here enjoy freedom and a legal capacity to formalize the specific contents of the core curriculum into subjects, and also to create compulsory subjects specific to that university itself, along with a wide array of elective subjects. In fact, each center interprets the official directives in a slightly different manner, depending upon 
their own objectives, curricula, and-above all-the resources and faculty members that integrate the departments involved in teaching LIS.

In Table 2 we see the course designations that partly or fully develop the contents pertaining to Cataloging, distributed by university, and by the degree obtained. The contents of Subject Headings and those of Classifications have been excluded from this analysis because they appear associated with the curricula of Content Analysis (Indexing and Abstracting). On the other hand, note that only a general analysis could be made from the the denominations of the subjects and the credit hours assigned to each. A detailed analysis of the contents of the programs of each subject is not possible, as we cannot obtain that information on the Web in most cases, and even when it is available, all of the course syllabi may not be presented in a uniform manner, making it impossible to attempt a comparative study.

Before entering into the analysis of Cataloging, a general matter to be addressed, reflected in Table 2, is the consideration of LIS in Spain as a discipline associated with Human Sciences as opposed to Social Sciences. The universities where the degree is not offered in a separate school, but instead in a department pertaining to a broader discipline, often situates LIS among the Humanities (Philosophy, Literature, Geography, and History). We believe this has had a negative impact on the orientation of students and teachers, and has hampered the development of scientific research in our specialized field.

Generally speaking, cataloging is represented in all of the curricular plans, though with noteworthy differences or imbalances in its configuration or denomination from one center to the next. Six out of the 12 LIS programs (Carlos III, Complutense de Madrid, La Coruña, León, Murcia, and Vic) maintain the unfortunate name "Document Analysis" for the contents of Cataloging. This obliges them to dedicate ample introductions to the study in these courses, until now known as Documentary Processing, or to differentiate between Formal Analysis and Content Analysis. The latter is nowadays irrelevant in the context of bibliographic databases, as we know. The study programs of the other six centers use the denomination "Cataloging," though we applaud the fact that Salamanca and Barcelona prefer the denomination "Descriptive Cataloging."

As for the distribution of the three degrees offered (Table 2), it is evident that, in Spain, cataloging is understood as a discipline belonging to the first cycle. That is, it is fundamentally and specifically for the formation of Diplomados. Within this three-year program, cataloging is represented in all of the universities by two or more subjects, and in many 
TABLE 2. Spanish Universities with Cataloging Curricula and Degrees

\begin{tabular}{|c|c|c|c|}
\hline $\begin{array}{l}\text { Universidad } \\
\text { Centro }\end{array}$ & Degrees & $\begin{array}{l}\text { Course Names } \\
\text { (R) Required or (O) Optional }\end{array}$ & $\begin{array}{l}\text { Length in } \\
\text { Credit } \\
(\mathrm{T}-\mathrm{P}) \\
\end{array}$ \\
\hline $\begin{array}{c}\text { Universidad de Alcalá de Henares } \\
\text { Facultad de Ciencias de la } \\
\text { Documentación }\end{array}$ & LD & $\begin{array}{l}\text { Gestión Evaluación de Catálogos } \\
\text { Automatizados (O) }\end{array}$ & $6(2-4)$ \\
\hline $\begin{array}{c}\text { Universidad Autónoma de } \\
\text { Barcelona } \\
\text { Facultat de Ciencies de la } \\
\text { Comunicació }\end{array}$ & LD & & \\
\hline \multirow[t]{2}{*}{$\begin{array}{c}\text { Universidad de Barcelona } \\
\text { Facultad de Biblioteconomia y } \\
\text { Documentación }\end{array}$} & $\mathrm{D} B$ and $\mathrm{D}$ & $\begin{array}{l}\text { Introducción a la Catalogación (R) } \\
\text { Catalogación Descriptiva (R) } \\
\text { Organización de Catálogos On Line (R) } \\
\text { Publicaciones Seriadas }(\mathrm{O})\end{array}$ & $\begin{array}{c}7,5(4-3,5) \\
7,5(4-3,5) \\
6(3-3) \\
4,5 \\
\end{array}$ \\
\hline & L B and D & & \\
\hline \multirow[t]{2}{*}{$\begin{array}{l}\text { Universidad Carlos III (Madrid) } \\
\text { Facultad de Humanidades, } \\
\text { Comunicación y Documentación }\end{array}$} & $D B$ and $D$ & $\begin{array}{l}\text { Análisis Documental I ( R) } \\
\text { Análisis Documental II (R) } \\
\text { Catalogación Automatizada ( R) } \\
\text { Catalogación Materiales Especiales (O) }\end{array}$ & $\begin{array}{l}8 \\
7 \\
7 \\
6\end{array}$ \\
\hline & L B and D & $\begin{array}{l}\text { Mantenimiento de Catálogos } \\
\text { Automatizados (O) }\end{array}$ & 6 \\
\hline \multirow{2}{*}{$\begin{array}{c}\text { Universidad Complutense (Madrid) } \\
\text { Escuela Universitaria de } \\
\text { Biblioteconomía y Documentación } \\
\text { Facultad de Ciencias de la } \\
\text { Información }\end{array}$} & $D B$ and $D$ & $\begin{array}{l}\text { Análisis Documental I }(\mathrm{R}) \\
\text { Análisis Documental II (R) } \\
\text { Fondos Bibliográficos Antiguos (O) } \\
\text { Catalogación Materiales Especiales (O) } \\
\end{array}$ & $\begin{array}{c}9(4,5-4,5) \\
6(3-3) \\
6 \\
6 \\
\end{array}$ \\
\hline & L B and D & & \\
\hline $\begin{array}{c}\text { Universidad de La Coruña } \\
\text { Facultad de Humanidades }\end{array}$ & D B and D & $\begin{array}{l}\text { Análisis Documental I (R) } \\
\text { Análisis Documental II (R) }\end{array}$ & $\begin{array}{c}12(6-6) \\
9(4,5-4,5) \\
\end{array}$ \\
\hline \multirow{2}{*}{$\begin{array}{c}\text { Universidad de Extremadura } \\
\text { Facultad de Biblioteconomía y } \\
\text { Documentación }\end{array}$} & $\mathrm{D} B$ and $\mathrm{D}$ & $\begin{array}{l}\text { Catalogación ( R) } \\
\text { Catalogación de Fondos Especiales (O) }\end{array}$ & $\begin{array}{l}5(2-3) \\
6(3-3) \\
\end{array}$ \\
\hline & $L B$ and $D$ & $\begin{array}{l}\text { Mantenimiento de Catálogos } \\
\text { Automatizados (O) }\end{array}$ & $6(1-5)$ \\
\hline \multirow[t]{2}{*}{$\begin{array}{c}\text { Universidad de Granada } \\
\text { Facultad de Biblioteconomía y } \\
\text { Documentación }\end{array}$} & $D B$ and $D$ & $\begin{array}{l}\text { Catalogación }(\mathrm{R}) \\
\text { Control de Autoridades }(\mathrm{O}) \\
\text { Catalogación de Materiales Especiales }(\mathrm{O})\end{array}$ & $\begin{aligned} & 5(0-5) \\
& 7,5(2,5-5) \\
& 7,5(2,5-5) \\
&\end{aligned}$ \\
\hline & L B and D & Gestión Automatizada de Catálogos (O) & $4,5(2-2,5)$ \\
\hline $\begin{array}{c}\text { Universidad de León } \\
\text { Facultad de Filosofía y Letras }\end{array}$ & $D B$ and $D$ & $\begin{array}{l}\text { Análisis Documental }(\mathrm{R}) \\
\text { Tratamiento Materiales Especiales }(\mathrm{O}) \\
\end{array}$ & $\begin{array}{l}10(4-6) \\
6(2-4) \\
\end{array}$ \\
\hline \multirow[t]{2}{*}{$\begin{array}{l}\text { Universidad de Murcia } \\
\text { Facultad de Ciencias de la } \\
\text { Documentación }\end{array}$} & $\mathrm{D} B$ and $\mathrm{D}$ & $\begin{array}{l}\text { Introducción al Análisis Documental (R) } \\
\text { Catalogación }(\mathrm{R}) \\
\text { Documentos Audiovisuales }(\mathrm{O}) \\
\end{array}$ & $\begin{array}{c}5(3-2) \\
7(4,5-2,5) \\
5(3-2) \\
\end{array}$ \\
\hline & L B and D & & \\
\hline Universidad Oberta de Catalunya & LD & & \\
\hline \multirow[t]{2}{*}{$\begin{array}{c}\text { Universidad de Salamanca } \\
\text { Facultad de Traducción y } \\
\text { Documentación }\end{array}$} & $D B$ and $D$ & $\begin{array}{l}\text { Catalogación Descriptiva I: } \\
\text { impresos modernos (R) } \\
\text { Organización de Catálogos en Línea (R) } \\
\text { Catalogación Descriptiva II: } \\
\text { Materiales Especiales O) } \\
\end{array}$ & $\begin{array}{c}10(3-7) \\
4,5 \\
4,5 \\
\end{array}$ \\
\hline & $\mathrm{LB}$ and $\mathrm{D}$ & Evaluación de Catálogos en Línea (O) & $4,5(1,5-3)$ \\
\hline
\end{tabular}


TABLE 2 (continued)

\begin{tabular}{|c|l|l|c|}
\hline $\begin{array}{c}\text { Universidad } \\
\text { Centro }\end{array}$ & Degrees & \multicolumn{1}{|c|}{$\begin{array}{c}\text { Course Names } \\
\text { (R) Required or (O) Optional }\end{array}$} & $\begin{array}{c}\text { Length in } \\
\text { Credit } \\
(\mathrm{T}-\mathrm{P})\end{array}$ \\
\hline $\begin{array}{c}\text { Universidad de Valencia } \\
\text { Facultad de Geografía e Historia }\end{array}$ & D B and D & $\begin{array}{l}\text { Catalogación y Clasificación (R) } \\
\text { Catalogación Automatizada (R) }\end{array}$ & $\begin{array}{c}9(6-3) \\
4,5(1,5-3)\end{array}$ \\
\hline $\begin{array}{c}\text { Universidad de Vic } \\
\text { Facultad de Ciencias Humanas, } \\
\text { Traducción y Documentación }\end{array}$ & L B and D & & 9 \\
\hline $\begin{array}{c}\text { Universidad de Zaragoza } \\
\text { Facultad de Filosofía y Letras }\end{array}$ & D B and D & $\begin{array}{l}\text { Análisis Documental ( R) } \\
\text { Formatos Bibliográficos y Catálogos } \\
\text { en Línea (R) } \\
\text { Catalogación de Materiales no } \\
\text { Librarios (O) }\end{array}$ & 12 \\
\hline
\end{tabular}

$\mathrm{LD}=$ Licenciado in Information Science (2nd cycle). $\mathrm{D} \mathrm{B}$ and $\mathrm{D}=$ Diplomado (3-yr. degree) in LIS. L B and $\mathrm{D}=$ Licenciado (5-yr. degree) in LIS. (T-P) = Theory-Practice. See Appendix for URL consulted.

cases by four, whose general characteristics may be summed up as follows: (1) In all curricular plans, the Cataloging of Serials and of Special Materials (Audiovisual Material, Music, Cartographic Material, and Computer Files) is considered a specific subject of an elective nature, separate from the Cataloging of Monographs; (2) Cataloging Electronic Resources and Internet Resources has not yet been incorporated into the contents of the study programs as an independent course; (3) of the 12 Universities, only five (42\%) include as compulsory within this first cycle, the subjects of Computerized Cataloging or OnLine Cataloging (this situation forces us to acknowledge that, in Spain, there may be Diplomados in LIS who, aside from other formative gaps or weaknesses concerning the organization, use, and maintenance of the online catalogs, may not have technical training in the use of MARC format, or in the computerized systems of Authority Control); and (4) only one curricular program, that of the University of Granada, grants special treatment to Authority Control by giving it a specific course, albeit with an elective character, of 7.5 credits.

As for the credit load, and according to the data shown in Table 2, the average of obligatory credits (theory and practice) assigned to cataloging in the Spanish curricular prgrams of the first cycle is 14. There is a noteworthy difference between those universities that dedicate some 20 credits to the subject area (Barcelona, Carlos III de Madrid, La Coruña, and Vic) and the schools that lend it only five credits (Granada and Extremadura). Between these two extremes we see the rest of the universities with a range of 10-15 credits. If, however, we also take into ac- 
count the elective credits pertaining to cataloging, the mean jumps to 19.7. Indeed, what is revealed by the data in Table 2 is that most curricular programs in LIS attempt to alleviate the lack of obligatory credit hours in cataloging by offering electives, mainly in the Diplomatura cycle but also in the Licenciatura in some cases. We should also point out that in the specific guidelines for the Licenciatura degree, cataloging is not represented in any of the core courses, and therefore, never generates obligatory subjects in the second cycle. In fact, one of the trademarks of the Spanish LIS Licenciatura degree (Table 2) is its scarcity. Out of the 11 universities that award this five-year degree, six (Autónoma de Barcelona, Barcelona, Complutense de Madrid, Murcia, Oberta de Catalunya, and Valencia) do not offer cataloging per se, and the others do so with only one course offering of the following characteristics: optional, of 5-6 class credit hours, and referring always to different aspects of the management or maintenance of computer catalogs or online cata$\operatorname{logs}$.

The data on the obligatory subjects of the first academic cycle can be broken down as to theoretical or practical contents as shown in Table 2. The average number of credits with respect to the theoretical contents of cataloging $(\mathrm{T})$ is 5.8, whereas the practical contents take up 6.6 credits. If we consider all courses together (obligatory and electives), these means are slightly different, with the increase seen on the side of the practical credits $(6.9 \mathrm{~T}$ and $8.6 \mathrm{P})$. We may state in general terms that the theoretical/practical distribution in all of the study plans is around 50\%, with the exception of universities such as Granada where cataloging has a predominantly practical orientation $(5 \mathrm{~T}$ and $15 \mathrm{P})$.

\section{Cataloging in Other Stages of Professional Instruction}

In Spain, instruction in the first university-level cycle culminates with the practicum of students in libraries, documentation centers, or archives. This practicum has a quatrimestral duration, and is carried out in public and private centers with which the Schools or Departments of Library and Information Science have cooperative agreements. Logically, the practica in cataloging have an important role within this formative stage, and are directed by the persons responsible for the centers, while supervised by the LIS professors.

At the same time, in view of the mobility from one university to another allowed Spanish students, it is possible to enroll in the second cycle if holding a Diplomatura degree, even when it is not specifcally in LIS. For this purpose, it is necessary to finish a course known as "Adap- 
tation" or "Complements of Formation," whose contents are practically identical in all of the universities listed in Table 2. This course involves 45 credits, and integrates all of the subject matter that is considered basic for formation; here, Cataloging and Classification are well represented as a general subject consisting of 10 credits.

\section{The Immediate Future: LIS in the Context of the EU}

In the ongoing academic year, the European universities, including those of Spain, are immersed in a process of convergence of the different national systems of higher education. In our case, the results of this process are far from definitive, and therefore, we cannot predict the situation that will be left for LIS studies, or the specific situation of cataloging therewithin. At this point in time, we can only describe the framework and the general directives of this convergence of the European Universities. The most important steps in the process of harmonization have been synthesized by L. Orera. ${ }^{21}$ Foremost is the Declaration of Bologne, a document drawn up in June 1999 and undersigned by 29 European nations, including Spain. The meetings of the EUA (European University Association) (Salamanca, March, 2001) and, finally, the declaration of Prague (undersigned by 33 European countries) have only come to back up the Declaration of Bologne. ${ }^{22}$ It addresses the creation of a common area for higher eduction in the framework of the European Union principles, as well as improved competitiveness of the European educational system in the broader international context. The year 2010 has been set for this undertaking, and the most important general principles to be achieved are:

- Organization of higher education into two cycles: a first cycle of three to four years of undergraduate education, and a second cycle leading to the degree of master or doctor, both with validity in the whole of the European Union workplace.

- The teaching system should take, as units of reference, the semester and the credit as implanted by the ECTS (European Credit Transfer System) in specific and consolidated programs such as "Erasmus" or "Socrates," where Spanish scholars have been participating for some years. Under this system, the credit does not only represent the time the student spends in class, but it computes the total volume of the work done (class attendance, practical tasks, work practicum, personal projects, exams, etc.). In this con- 
text, 30 credits would represent the work volume of a semester, 60 of an academic course, and 20 in a trimester.

- The curricula and the corresponding degrees of each country should be legible and comparable in the framework of the European Union. The academic degree, the courses taken and their equivalence in credits, and the grades obtained should all be uniform or easily converted.

Consequently, in the case of Spain, the curricular changes needed are considerable. Although we have already implanted the credit system, it requires adaptation to the new European system, as at present it does not take into account the full work load of the student, but rather only the hours of class scheduled. As far as the organization of cycles is concerned, the three that currently exist should be reduced to two: an undergraduate cycle of four years of duration, and with a predominantly professional orientation, and a second graduate cycle of specialization, preparing the student to design, plan, and evaluate units and systems of information, as well as to carry out research and apply the results of research generated in the field of choice. From our vantage point, these changes will markedly affect LIS studies; and even if we cannot provide data for their evaluation, it can be foreseen that the professional orientation in our degree area will be reinforced with the adaptation to the common European framework. Therefore, basic subjects in the formation of librarians, as is cataloging, will no doubt wield greater relevance.

\section{CONCLUSIONS}

In the first place, we must positively appraise the consideration of cataloging as a core and compulsory subject within all of the curricular programs of Spain's schools of Library and Information Science. This means that it is upheld as fundamental material in achieving the objectives of the first cycle of formation of the professional librarian. Nonetheless, this does not take away from the important deficiencies that the present study identifies: the incorrect characterization and description of the subject matter, its limited obligatory class load, and its heterogeneous formulation.

At the same time, however, the diversity of the different programs has made it impossible to carry out an analysis of the precise contents of the subjects taught. Although this situation may seem logical or justifiable given the comparative "youth" of LIS studies in Spain, consensus 
among the different universities is urgently needed to strive toward homogeneity in the foundations, contents, and orientations of the subject. We might also hope that the adaptation to the common European framework will allow us to introduce modifications in the denomination of the subject matter, increase the corresponding number of credits, and reinforce contents that relate cataloging and bibliographic control with the latest technology.

\section{REFERENCES}

1. Gorman, M. "Bibliographic Control or Chaos: An Agenda for National Bibliographic Services in the 21st Century" IFLA Journal 27(2001): 307-313.

2. Marco, G.A. "The demise of the American core curriculum" Libri 44(1994): 175-189.

3. ALA. Standards for accreditation of Master's programs in Library and Information Studies. http://www.ala.org/alaorg/oa/standard.html [consulted 2003-10-04].

4. IFLA. Sección de Escuelas de Biblioteconomía. Normas para Escuelas de Biblioteconomía. (Madrid: ANABAD, 1977).

5. UNESCO. Armonización de la capacitación en materia de Biblioteconomía, Ciencias de la Información y Archivística. PGI-87/WS/2. (París: UNESCO, Programa General de Información, 1987).

6. Saunders, W.L. Guidelines for curriculum development in information studies. PGI-78/WS/27. (París: UNESCO. Programa General de Información, 1987).

7. Large, J.A. Un programa modular de estudios de la información. PGI-87/ WS/5. (París: UNESCO. Programa General de Información, 1987).

8. Delgado López-Cózar, E. "La enseñanza de la biblioteconomía y documentación: una perspectiva global" Boletín de la Asociación Andaluza de Bibliotecarios 35(1994): 27-54.

9. Orera Orera, L. "La evolución en la formación de los bibliotecarios." Documentación de las ciencias de la Información 24(2002): 167-188.

10. Cid, P., Recoder, M.J. "La licenciatura de documentación: estudio de las propuestas formuladas en España para su realización.” In: IV Jornadas Españolas de Documentación. (Gijón 1994). Gijón: FESABID, 1994. p. 611-615.

11. López Yepes, J. "La licenciatura en documentación, marco formativo de un nuevo profesional." Revista General de Información y Documentación 5(1995): 33-69.

12. Solano Macías, C.; López Pujalte, C. "Perfil multidisciplinar de los nuevos profesionales de la información: principales áreas de conocimiento en los estudios de Biblioteconomía y Documentación." Actas de las VI Jornadas Españolas de Documentación. Los sistemas de información al servicio de la sociedad (Valencia 1998). Valencia: FESABID, p. 855-871.

13. Carrizo Sainero, G.; Ayuso Sánchez, M.J.; Sánchez Domínguez, M.C. “Análisis comparativo de los diferentes programas docentes en Fuentes de Información en las universidades y escuelas de Biblioteconomía y Documentación en España." Actas del $V$ encuentro de EDIBCIC. La formación de profesionales e investigadores de la información para la sociedad del conocimiento. (Granada 2000). Granada: Facultad de Biblioteconomía y Documentación, 2000, p. 82-94. 
14. González Molina, A., Navarrete Cortes, J. “La enseñanza de las tecnologías de la información en las Escuelas Universitarias de Biblioteconomía y Documentación en España." VIII Jornadas Bibliotecarias de Andalucía. (Huelva 1994). Huelva: Asociación Andaluza de Bibliotecarios, Diputación Provincial, 1995, p. 387-396.

15. Delgado López-Cózar, E. "La enseñanza de metodología de la investigación en las Licenciaturas en Documentación en España” Homenaje a J. A. Martín Fuertes: la documentación para la investigación. León: Universidad, 2002, p. 145-167.

16. Salvador Olivan, J.A. "Formación en recuperación de información: análisis de los cursos y asignaturas en las escuelas de Biblioteconomía y Documentación de Norteamérica y España.” Documentación de las Ciencias de la Información 25(2002): 189-215.

17. http://www.ine.es/inebase/cgi/um?M=\%2Ft13\%2Fp405\&O=inebase $\& \mathrm{~N}=\& \mathrm{~L}=$ [consulted 2003-10-29].

18. http://www.ine.es/inebase/cgi/um?M=\%2Ft13\%2Fp405\&O=inebase $\& \mathrm{~N}=\& \mathrm{~L}=$ [consulted 2003-10-29].

19. Frias, J.A. "Las relaciones entre análisis documental y catalogación: su representación en el plan de estudios de la Universidad de Salamanca." Proceeding of the first ISKO-Spain Conference (Madrid 1993). Edited by F. J. Garcia Marco. Zaragoza, 1995, p. 145-57.

20. Ruiz-Perez, R. "Consequences of Applying Cataloguing Codes for Author Entries to the Spanish National Library Online Catalogs." Cataloging \& Classification Quarterly 32, 3(2001): 31-55.

21. Orera Orera, L. "La evolución en la formación de los bibliotecarios." p. 185.

22. Declaración conjunta de los Ministros Europeos de Educación, reunidos en Bolonia el 19 de Junio de 1999 <http://www.universia.es/contenidos/universidades/ documentos/Universidades_docum_bolonia.htm>.

Docampo, D. La declaración de Bolonia y su repercusión en la estructura de las titulaciones en España <http://www.gts.tsc.uvigo.es/ ddocampo/galinbol.html>. 


\title{
APPENDIX
}

URLs [Consulted, Nov. 2003]

\author{
Universidad de Alcalá de Henares: \\ http://www.uah.es/organ/facultades_escuelas/lstAsignaturas_v2.asp? \\ CodCentro $=109 \&$ CodPlan $=640$
}

Universidad Autónoma de Barcelona:

http://www.uab.es/estudis/dosframes.htm

Universidad de Barcelona:

http://www.ub.es/biblio/

Universidad Carlos III (Madrid):

http://www.uc3m.es/uc3m/gral/ES/ESCU/escu11b.html

Universidad Complutense (Madrid):

http://www.uc3m.es/uc3m/gral/ES/ESCU/escu51b.html

http://berceo.eubd.ucm.es/html/docs/estudios/plan/nuevo.html

Universidad de La Coruña:

http://www.udc.es/cap4c/

Universidad de Extremadura:

http://alcazaba.unex.es/

Universidad de Granada:

http://www.ugr.es/ fbd/Planes_de_estudio/Diplomatura.htm

http://www.ugr.es/ fbd/Planes_de_estudio/Licenciatura.htm

Universidad de León:

http://www.unileon.es/estudios/filosofia/plan_bibliot.htm

\section{Universidad de Murcia:}

http://www.um.es/fccd/

Oberta de Catalunya:

http://www.uoc.edu/web/esp/estudios/estudios_uoc/documentacion/ documentacion_cuadro.htm

Universidad de Salamanca:

http://exlibris.usal.es 
Universidad de Valencia:

http://www.uv.es/dise/estudi/plans/02bid.html

Universidad de Vic:

http://www.uvic.es/central/campus/gabinet/ca/guies/fchtd/biblioteconomia.pdf

Universidad de Zaragoza:

http://ebro3.unizar.es:8080/acad/FMPro?-db=w\%5fcentros.fp5\&-format=centro. htm\&-lay=cgi\&-sortfield $=$ cod $\% 5$ fcentro $\&$-recid $=28 \&$-findall $=$ 